\title{
Variation in Egg Yolk Colour in Different Systems of Rearing Laying Hens
}

\author{
Petr Dvořák ${ }^{1}$, Pavel Suchý², Eva Straková ${ }^{2}$, Jana Doležalová ${ }^{1}$ \\ ${ }^{1}$ Department of Biochemistry, Chemistry and Biophysics, ${ }^{2}$ Department of Nutrition, Animal Breeding and \\ Animal Hygiene, Faculty of Veterinary Hygiene and Ecology, University of Veterinary and Pharmaceutical \\ Sciences Brno, Czech Republic \\ Received September 30, 2008 \\ Accepted March 8, 2010
}

\begin{abstract}
A total of 72 laying hens (ISA BROWN hybrid combination) were divided into two groups. Thirty-six layers in the first group were reared on litter while the second group of layers was reared using the cage rearing system. Samples of eggs were collected from both groups for a period of seven months. Yolk colour was determined using a portable spectrophotometer using a newly developed method, which complied with the CIELAB system. Yolk colour indicator L* decreased for the rearing system on litter, i.e. egg yolk colour became darker in the course of the whole experiment $(\alpha=0.05)$. Indicator $a^{*}$ showed a distinct increase in the case of the rearing system on litter, with the differences being significant $(\alpha=0.05)$ over the last three months of the experiment. Differences for the whole experiment were highly conclusive $(\alpha=0.01)$, as seen from the increasing red colour intensity. Similarly, indicator $b^{*}$ also increased, i.e. egg yolk was of more distinct yellow colour. In the case of the cage-rearing system, egg yolk colour indicators correlated well with egg weight indicators, as compared to the rearing system on litter. The rearing system on litter resulted in significantly increased intensity of orange colour compared to the cage rearing system.
\end{abstract}

CIELAB, spectrophotometer, food colour, litter, cage

Quality indicators of eggs depend not only on the nutrition of laying hens and intravital factors but also on the rearing system used.

According to Wan Den Brandt et al. (2004), it is more difficult to maintain stable quality of eggs in the outdoor rearing system than in the cage rearing system. He investigated the effect of two rearing systems (outdoor vs. cages) on indicators such as egg weight, egg white, egg yolk, the content of the egg shell, the level and the $\mathrm{pH}$ of the white, and dry matter content of the white and the yolk. Characteristics such as egg weight, the content of the shell, the level and the $\mathrm{pH}$ of the white, and the levels of dry matter in the white and the yolk correlated with the age of layers and the rearing system. Yolk colour of eggs from layers reared outdoors was significantly darker.

The quality of eggs from white (LSLs) and brown layers (LTs) reared in three different housing systems (cages, aviaries, and intensive outdoor rearing) were compared. LSLs gave eggs of better quality as compared to LTs. LSLs showed significantly higher levels of Haugh units (HU) (91.62), egg yolk weight, strength and density of the shell but had significantly lower values for egg yolk colour (12.9) and the occurrence of eggs with meat and blood spots was lower. The comparison of egg quality traits for the rearing systems investigated revealed that none of the systems had superior advantages over the others. The egg yolk weight was increased in the cage system. The highest colour intensity of egg yolk was found in the outdoor rearing system with LSLs and in the cage rearing system with LTs (Leyendecker et al. 2001).

Quality indicators of eggs were also monitored in the ISA Brown layers in the cage rearing system, on deep litter and in the outdoor rearing system in the course of one year. These three rearing systems differed significantly in the following indicators: the average egg weight, egg length, egg width, colour score of the shell and the score of shell cleanliness (Pavlovski et al. 1994a).

Address for correspondence:

Prof. MVDr. Petr Dvořák, CSc.

Department of Biochemistry, Chemistry and Biophysics

Faculty of Veterinary Hygiene and Ecology

University of Veterinary and Pharmaceutical Sciences Brno,

Palackého 1-3, 61242 Brno, Czech republic

Phone: +420541562608

E-mail: dvorakp@vfu.cz

http://www.vfu.cz/acta-vet/actavet.htm 
Similar to the results reported by Mohan et al. (1991), the egg weight and the shell thickness in the eggs laid by layers reared in cages were greater compared to the eggs from the layers kept on deep litter. The egg shape index, yolk index and the white content (in percentage) were significantly higher on deep litter compared to the cage rearing system.

The results from the surroundings of Nimakkal, India, from 5 farms that employed the rearing system with deep litter and from 5 farms with the cage rearing system showed that indicators such as egg weight, the HU score, the egg shape index, and white and yolk indices were significantly higher $(\alpha<0.01)$ in the cage rearing system while no differences between the two rearing systems were found in yolk colour (Muthusamy and Viswanathan 1999).

Sauveur (1991) has reported the results of 25 studies (conducted over a period of 15 years) which dealt with the impact of rearing conditions (outdoor rearing, deep litter, and cages) on both the composition and the quality of eggs. The type of the rearing system had no effect on egg weight and egg composition except for the levels of linoleic acid and cholesterol. The yolk colour was not affected by the rearing conditions.

The colour of the egg yolk is an important quality feature of the egg yolk, being attributed to the high quality of eggs and the products made of eggs. Egg producers make efforts to produce eggs whose yolk would have rich yellow colour and therefore use suitable feeds to reach such a goal. Natural pigments can be replaced by synthetic pigments that are approved as components of feeding mixtures for layers (Anonymous 1996, 2000). As mentioned above, there are a number of other factors besides nutrition which may have a major impact on the quality of eggs. With the cage rearing systems being banned, a new challenging question has arisen: how can outdoor housing technologies affect the quality of eggs? Wan Den Brand et al. (2004) dealt with the relationship between yolk colour and the housing system. They reported that the yolk from eggs laid by layers reared in outdoor housing systems was darker than that from layers housed in cages.

Colour perception depends on chemical and physical properties of the yolk, the quality and intensity of lighting produced by a light source and on the particular observer. The colour can be determined subjectively by sight using the Yolk Colour Fan ${ }^{\circledR}$ scale (Roche) (Voilleumier 1969) for comparison. The scale was determined using colorimetry and assessed in the 3D CIE colour diagram (Commission Internationale de l'Eclaraige (McLaren 1980)). However, this determination is not sufficiently accurate.

The surface colour of foodstuff can also be determined objectively using portable instruments (Dvořák et al. 2001) such as spectrocolorimeters with predefined parameters (such as $\mathrm{d} / 8^{\circ}$ spherical geometry, $\mathrm{D}_{65}$ light source, the standard angle of the observer being $10^{\circ}$ and at different diameters of the opening, e.g. $8 \mathrm{~mm}$ ). The results are expressed using the CIE international colorimetric system $\mathrm{L}^{*} \mathrm{a} * \mathrm{~b}^{*}$ (CIE 1986). Calibration is based on the black $\left(\mathrm{L}^{*}=0\right)$ and white $\left(\mathrm{L}^{*}=100\right)$ standards.

The main aim of the present study was to investigate variations in egg yolk colour in different rearing systems using the Colour-guide sphere spectrophotometer as an objective method.

\section{Materials and Methods}

ISA Brown layers (51-52 weeks old) were reared on litter or in cages in the accredited experimental enclosure of the Department of Nutrition, Animal Breeding and Animal Hygiene, University of Veterinary and Pharmaceutical Sciences Brno, Czech Republic, in compliance with the requirements specified in the respective technological instructions for the rearing of ISA Brown hybrid combination laying hens. In the deep litter system, 36 layers were kept in a pen (area of $5.5 \mathrm{~m}^{2}$ ) with wood shavings on the floor. The pen was equipped with tube feeders, bell drinkers and nests. In the cage system, 36 layers were reared individually in three-tier cages. Each cage had an area of $50 \times 30 \mathrm{~cm}$ and automatic nipple drinker.

During a seven-month experiment, layers were fed with commercial complete feed mixtures: N1 (until Month 5 of the laying period) and N2 (from Month 5 of the laying period until the end of the experiment). Feed mixtures were fed ad libitum and feed consumption was evaluated once a month. The compositions of N1 and N2 feed 
Table 1. Ingredient and nutrient composition of feed mixtures N1 (until Month 5 of the laying period) and N2 (from Month 5 of the laying period until the end of the experiment)

\begin{tabular}{|c|c|c|c|c|c|}
\hline Ingredient $(\%)$ & N1 & $\mathrm{N} 2$ & Nutrient $\left(\mathrm{g} \cdot \mathrm{kg}^{-1}\right)$ & N1 & N2 \\
\hline Wheat & 25.68 & 31.49 & Dry matter & 899.3 & 894.0 \\
\hline Corn & 30.00 & 35.00 & Crude protein & 185.0 & 161.5 \\
\hline Soyabean meal & 20.30 & 15.50 & Fat & 56.6 & 39.7 \\
\hline Soyabean oil & 3.25 & 1.50 & Fibre & 35.3 & 31.5 \\
\hline Lupin meal & 10.00 & 6.00 & Nitrogen-free extract & 498.3 & 542.0 \\
\hline L-Lysine $\mathrm{HCl}$ & 0.14 & 0.15 & Starch & 345.5 & 420.1 \\
\hline $\begin{array}{l}\text { Methionine hydroxy } \\
\text { analogue }\end{array}$ & 0.26 & 0.20 & Organic matter & 775.2 & 774.7 \\
\hline L-Threonine & 0.05 & 0.06 & Ash & 124.1 & 119.3 \\
\hline Calcium carbonate & 4.20 & 4.90 & $\mathrm{Ca}$ & 36.0 & 35.3 \\
\hline $\begin{array}{l}\text { Calcium carbonate } \\
\text { (coarse-grained) }\end{array}$ & 4.00 & 3.50 & $\mathrm{P}$ & 7.2 & 6.3 \\
\hline Sodium chloride & 0.42 & 0.23 & $\mathrm{Mg}$ & 1.6 & 1.5 \\
\hline \multirow[t]{8}{*}{ Vitamin premix } & 0.20 & 0.20 & $\mathrm{Na}$ & 1.9 & 1.6 \\
\hline & & & $\mathrm{K}$ & 7.1 & 6.2 \\
\hline & & & Lys & 8.6 & 7.5 \\
\hline & & & Met & 4.3 & 3.7 \\
\hline & & & Thre & 6.2 & 5.6 \\
\hline & & & Arg & 13.1 & 10.6 \\
\hline & & & Ile & 6.8 & 5.8 \\
\hline & & & $\mathrm{ME}\left(\mathrm{MJ} \cdot \mathrm{kg}^{-1}\right)$ & 11.7 & 11.3 \\
\hline
\end{tabular}

mixtures are presented in Table 1. The feed mixtures only consisted of plant-based components. Meal made from the yellow lupine variety JUNO seeds, which is also an important source of plant pigments (Dvořák et al. 2007), was one of the components. No artificial colourings were used, natural pigments originated from feed components.

At one-month intervals, 36 eggs from each rearing system were analysed. Egg weight and weights of yolk, white, and shell were determined. Furthermore, the laying rate $(\%)$ was calculated as the ratio between the number of laid eggs and the number of feeding days.

For yolk colour determination, egg yolk was separated from the white prior to measurement and placed on a Petri dish sized $50 \mathrm{~mm}$ in a diameter, then covered with a thin food foil. The colour was determined using a spectrophotometric method in the CIELAB system using the Colour-Guide Sphere Spex portable spectrophotometer (BYK Gardner, Germany) excluding gloss, by placing the instrument perpendicular to the foil. Prior to measurement, the instrument was calibrated to the food foil used. All measurements were performed three times and the final value was calculated as the average of the three values measured (Dvořák et al. 2005).

The means of egg weight indicators and laying rate calculated for the whole experimental period were compared using $t$-test. The data were statistically analysed for each indicator $\left(\mathrm{L}^{*}, \mathrm{a}^{*}, \mathrm{~b}^{*}\right)$ in each month. The effect of the rearing system on egg yolk colour indicators was tested using two-factor ANOVA (MS EXCEL; $\alpha$ $=0.05)$. Differences in a particular month were tested using $t$-test $(\alpha=0.05)$. Graphs showing the variation in yolk colour indicators throughout the laying period were processed as fifth-degree polynomial functions (MS EXCEL). Relationships between yolk colour indicators and both egg weights and laying rate were determined using correlation analysis.

\section{Results and Discussion}

Indicator $\mathrm{L}^{*}$ did not show a significant $(\alpha=0.05)$ difference in the light shade of the egg yolk for individual months (Fig. 1). A decrease in the average value of indicator L* in the litter rearing system indicates the darkening of the egg yolk. Indicator L*, which represents light shade intensity $(0-$ black, 100 - white), exhibited a steady difference (Fig. 1$)$. As a result, the general trend of both curves was significantly different $(\alpha=0.05)$, as evaluated using ANOVA. This proves that the yolk in eggs from the layers reared on litter contains higher concentrations of colour pigments. 


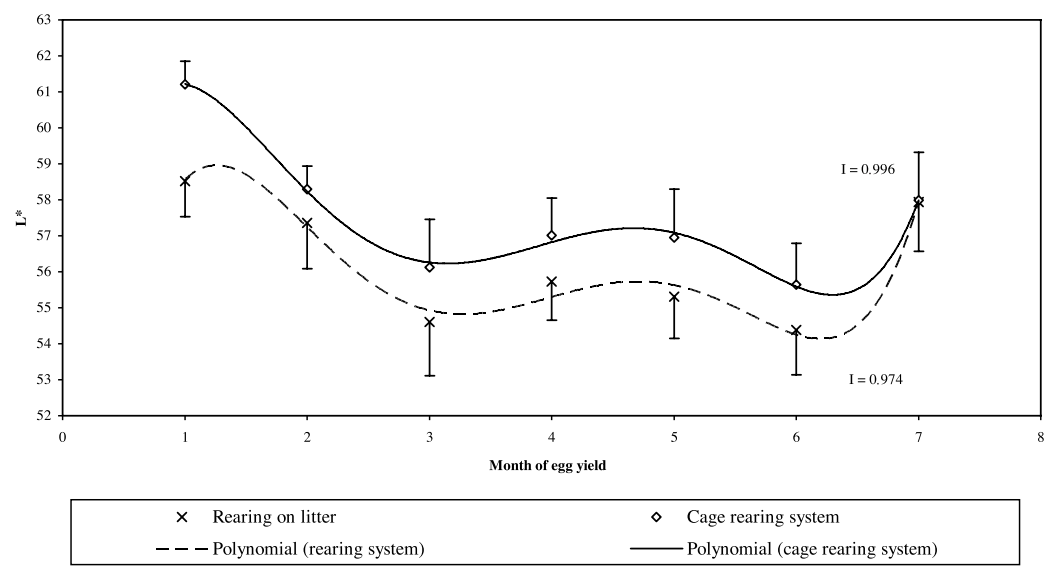

Fig. 1. Variation in yolk colour indicator $\mathrm{L}^{*}$ in the cage and litter rearing systems (mean and SEM; total 252 eggs)

Indicator $\mathrm{a}^{*}$ reflects the changes in the area of red-colour wavelengths and can reach a maximum in sharply red colour $(+120)$ or a minimum in green-blue colour $(-80)$. Egg yolk of layers reared on litter showed significant $(\alpha=0.05)$ increase in indicator $a^{*}$, particularly during the last three experimental months (Fig. 2). The differences between average values reached a maximum at the end of the experiment, i.e. in Month 7 (Fig. 2), representing an overall significant difference (ANOVA $\alpha=0.01$ ) between both curves at the given low variability (Fig. 2). Egg yolk from the layers reared on litter had therefore more distinct red-orange colour which consumers demand.

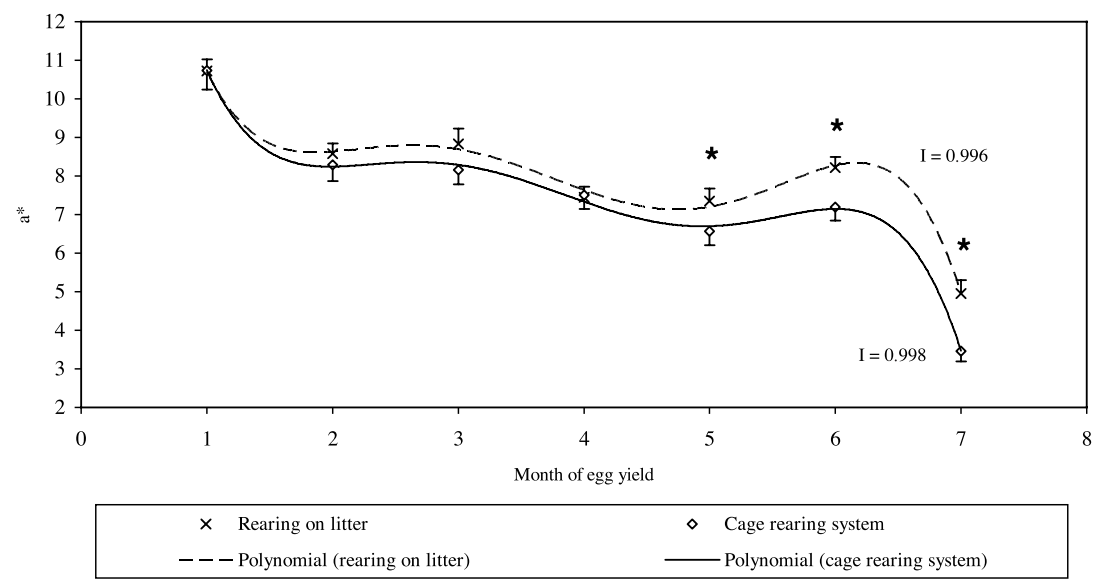

Fig. 2. Variation in yolk colour indicator $\mathrm{a}^{*}$ in the cage and litter rearing system (mean and SEM; total 252 eggs)

A significant increase in yolk colour indicator $b^{*}$ was found only in three months (Fig. 3). Indicator $b^{*}$ represents the transition from the yellow colour $(+120)$ to the blueviolet colour $(-80)$. We found that absolute value of indicator $b^{*}$ affected the shade of red colour towards the yellow-orange colour (the range of determined values $31-42$ is in the yellow region). Individual differences between both rearing systems are illustrated in Fig. 3 . When comparing both curves, one can see the trend of variations in indicator $b^{*}$ with the 


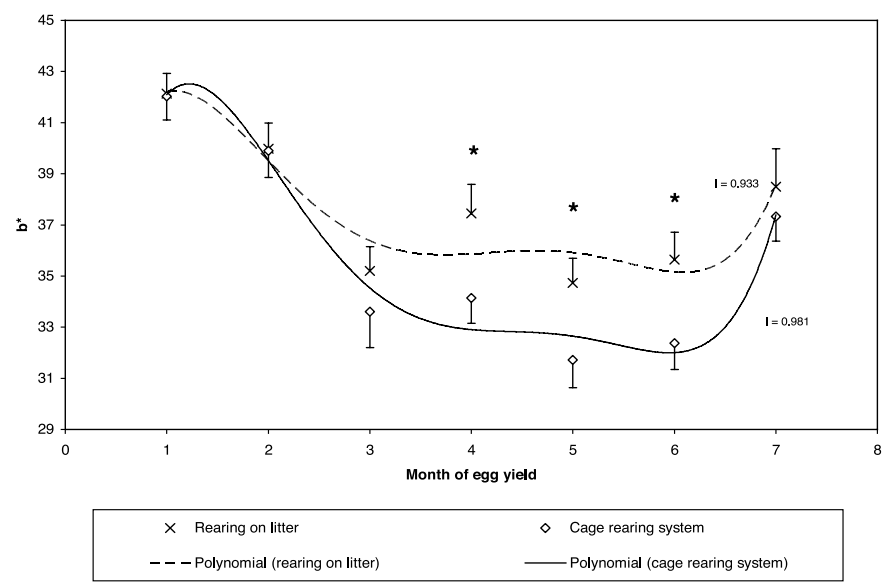

Fig. 3. Variation in yolk colour indicator $b^{*}$ in the cage and litter rearing system (mean and SEM; total 252 eggs)

rearing system used. Egg yolk colour tended to be of more intensive yellow colour in the litter rearing system. Differences were significant $(\alpha=0.05)$.

Different colours of eggs can be explained in terms of two aspects: individual egg components had different weights depending on the laying rate (Table 2) and the litter was possibly consumed by hens. In the litter rearing system, the weights of the egg, yolk,

Table 2. Egg weight indicators and laying rate in the cage and litter rearing systems

\begin{tabular}{|l|c|c|}
\hline Indicator & Cage & Litter \\
\hline Egg weight $(\mathrm{g})$ & $59.60 \pm 2.05^{\mathrm{a}}$ & $61.17 \pm 2.09^{\mathrm{b}}$ \\
\hline Yolk weight $(\mathrm{g})$ & $15.75 \pm 0.86^{\mathrm{a}}$ & $16.20 \pm 0.94^{\mathrm{b}}$ \\
\hline White weight $(\mathrm{g})$ & $36.61 \pm 0.97^{\mathrm{a}}$ & $37.83 \pm 0.94^{\mathrm{b}}$ \\
\hline Shell weight $(\mathrm{g})$ & $7.20 \pm 0.26$ & $7.23 \pm 0.22$ \\
\hline Laying rate $(\%)$ & $83.41 \pm 5.22^{\mathrm{a}}$ & $69.24 \pm 5.34^{\mathrm{b}}$ \\
\hline
\end{tabular}

Data are means \pm standard error of mean from the whole experimental period $(n=252$ eggs).

${ }^{\mathrm{a}, \mathrm{b}}$ Means within the same row differ significantly $(t$-test; $\alpha<0.05)$. and white were significantly higher at lower laying rate in comparison to the cage rearing system $(69.24 \%$ vs. $83.41 \%)$. These findings differ from those reported by Mohan et al. (1991) and Pavlovski et al. (1994a).

Negative correlations between yolk light shade and egg weight $(\mathrm{r}=-0.929)$, yolk weight $(\mathrm{r}=-0.811)$ and white weight $(r=-0.938)$ were found for the cage rearing system; in the litter rearing system such relationships were less significant (Table 3). This indicates that in the cage rearing system, the heavier the egg, the lower the indicator $\mathrm{L}^{*}$, and thus the lighter the egg yolk. Correlations of indicators $\mathrm{a}^{*}$ and $\mathrm{b}^{*}$ with the weights of individual components of the egg in both technologies are balanced (Table 3 ) and relatively low (ranging from -0.434 to -0.848 ).

Table 3. Correlation coefficients between egg yolk colour indicators ( $\left.\mathrm{L}^{*}, \mathrm{a}^{*}, \mathrm{~b}^{*}\right)$ and both egg weight indicators and laying rate in the cage and litter rearing systems $(n=252)$

\begin{tabular}{|l|c|c|c|c|c|c|}
\hline \multirow{2}{*}{ Egg indicators } & \multicolumn{2}{|c|}{$\mathrm{L}^{*}$} & \multicolumn{2}{|c|}{$\mathrm{a}^{*}$} & \multicolumn{2}{c|}{$\mathrm{b}^{*}$} \\
\cline { 2 - 7 } & Cage & Litter & Cage & Litter & Cage & Litter \\
\hline Egg weight $(\mathrm{g})$ & -0.929 & -0.687 & -0.687 & -0.722 & -0.878 & -0.838 \\
\hline Yolk weight $(\mathrm{g})$ & -0.811 & -0.578 & -0.848 & -0.813 & -0.800 & -0.767 \\
\hline White weight $(\mathrm{g})$ & -0.938 & -0.797 & -0.435 & -0.544 & -0.843 & -0.878 \\
\hline Shell weight $(\mathrm{g})$ & -0.832 & -0.473 & -0.762 & -0.867 & -0.840 & -0.681 \\
\hline Laying rate $(\%)$ & -0.616 & -0.099 & -0.484 & -0.027 & -0.269 & -0.063 \\
\hline
\end{tabular}


The rearing of layers on litter led to significantly higher weights of both the egg and egg yolk at a lower laying rate (Table 2). Yolk might have contained higher levels of colour pigments (higher value of indicator $\mathrm{L}^{*}$ ) and was therefore generally darker. In orange yolk colour intensity (indicator $\mathrm{a}^{*}$ ), there was, on average, $69 \%$ dependence on the yolk weight. Correlation coefficients for litter and cage rearing systems were -0.813 and -0.848 , respectively. Since the feed consumption was the same in both rearing systems, it is assumed that the litter might have served as a feed supplement. The increased yolk indicator a* can only be explained by of the presence of pigments in the consumed litter or layers on litter are coprophagous and would intake considerably more pigment than caged layers.

As reported by Muthusamy and Viswanathan (1999) and Pavlovski et al. (1994b), no differences in yolk colour were found between the rearing systems. However, egg colour in our experiment was determined using a more objective method which eliminates the limited perception of colours by the human eye.

In conclusion, the impact of the rearing system on the egg yolk colour was confirmed. The results of the experiment confirmed that the litter rearing system had a significantly positive effect on the yolk colour compared to the cage system. Our results are in good agreement with those reported by Wan Den Brand et al. (2004). The rearing systems where laying hens are housed on litter can be evaluated positively as they provide eggs with the yolk of distinct orange colour which consumers prefer.

\section{Změna barvy žloutku v závislosti na technologii chovu slepic}

Sedmdesát dva nosnic hybridní kombinace ISA BROWN bylo rozděleno do dvou skupin. První skupina 36 nosnic byla chována na podestýlce a druhá skupina byla chována v klecové technologii. Po dobu sedmi měsíců byly u obou skupin odebírány vzorky vajec. Stanovení barvy žloutku se provádělo pomocí přenosného spektrofotometru novou metodou, která odpovídá systému CIELAB. U ukazatele L* došlo k poklesu hodnoty u chovu na podestýlce, což poukazuje na ztmavnutí žloutku vajec v průběhu celého pokusu $(\alpha=0,05)$. U ukazatele $\mathrm{a}^{*}$ byl patrný nárůst hodnot $\mathrm{u}$ chovu na podestýlce, přičemž poslední tři měsíce pokusu byly rozdíly statisticky průkazné $(\alpha=0,05)$. Rozdíly za celý pokus pak byly vysoce průkazné $(\alpha=0,01)$, což dokazuje nárůst červené barvy. Obdobně u ukazatele b* došlo také k nárůstu hodnot, tedy k zvýraznější žluté barvě. Ukazatele barvy žloutku s ukazateli hmotnosti vajec při klecovém odchovu vzájemně více korelovaly, než u chovu na podestýlce. Podestýlková technologie vedla statisticky průkazně k oranžovější barvě žloutku ve srovnání s technologií chovu v klecích.

\section{Acknowledgement}

This study was funded by the grant No. MSM6215712402 "Veterinary Aspects of Food Safety and Quality" from the Ministry of Education, Youth and Sport of the Czech Republic.

\section{References}

Anonymous 1996: Act No. 91/1996 Coll. concerning feeds.

Anonymous 2000: Regulation of the Ministry of Agriculture No. 451/2000 Coll., which implements Act No. 91/1996 Coll., concerning feeds, as amended by Act No. 244/2000 Coll.

CIE 1986: Colorimetry, $2^{\text {nd }}$ ed., CIE Publications No. 15.2. Commission Internationale de l'Eclaraige, Vienna.

Dvořák P, Kunová J, Straková E, Suchý P, Kunová V 2005: Changes In the colour and the acidity number of egg yolk upon irradiation. Eur Food Res Technol 221: 348-352

Dvořák P, Musilová H, Švarcová I 2001: On-line measurements of colour of pork. Fleischwirtschaft 81: 89-91

Dvořák P, Straková E, Kunová J, Kunová V 2007: Variation in egg yolk colour with the composition of the feeding mixture for laying hens. Acta Vet Brno 76: 77-82

Leyendecker M, Hamann H, Hartung J, Kamphues J, Ring C, Glunder G, Ahlers C, Sander I, Neumann U, Distl O 2001: Analysis of genotype-environment interactions between layer lines and hen housing systems for performance traits, egg quality and bone breaking strength. $2^{\text {nd }}$ communication: egg quality traits. Züchtungskunde 73: 308-323 
McLaren K 1980: Colour Research and Application 5: 139-143

Mohan B, Mani V, Nagarajan S 1991: Effect of different housing systems on the physical qualities of commercial chicken eggs. Indian J Poult Sci 26: 130-131

Muthusamy P, Viswanathan K 1999: Influence of rearing system on the egg uality traits of commercial layers. Indian Vet J 76: 533-536

Pavlovski Z, Hopic S, Vracar S, Masic B 1994a: The effect of housing system on internal egg quality traits in small flocks of layers. Biotehnologija u Stocarstvu 10: 37-43

Pavlovski Z, Vracar S, Masic B 1994b: The effects of housing system on external egg quality traits in small flocks of layers. Biotehnologija u Stocarstvu 10: 13-19

Sauveur B 1991: Effect of method of rearing of fowls on egg characters. Prod Anim 4: 123-130

Vits A, Weitzenburger D, Hamann H, Distl O 2005: Influence of different small group systems on the production traits, egg quality and bone breaking strength of laying hens. $1^{\text {st }}$ Communication: production traits and egg quality. Zuchtungskunde 77: 303-323

Voilleumier JP 1969: The Roche yolk colour fan - an instrument for measuring yolk colour. Poult Sci 48: 787-779

Wan Den Brand H, Parmentier HK, Kemp B 2004: Effects of housing system (outdoor vs cages) and age of laying hens on egg characteristics. Br Poult Sci 45: 745-752 